\title{
EngagedScholarship@CSU
}

$2-1-2004$

\section{Technology in Nursing Education}

Cheryl Delgado

Cleveland State University, c.delgado@csuohio.edu

Follow this and additional works at: https://engagedscholarship.csuohio.edu/nurs_facpub

Part of the Nursing Commons

How does access to this work benefit you? Let us know!

Publisher's Statement

Copyright @ 2004 Wolters Kluwer Health, Inc. Lippincott Williams \& Wilkins

\section{Recommended Citation}

Delgado, Cheryl, "Technology in Nursing Education" (2004). Nursing Faculty Publications. 14.

https://engagedscholarship.csuohio.edu/nurs_facpub/14

This Article is brought to you for free and open access by the School of Nursing at EngagedScholarship@CSU. It has been accepted for inclusion in Nursing Faculty Publications by an authorized administrator of EngagedScholarship@CSU. For more information, please contact library.es@csuohio.edu. 


\section{Reflections}

\author{
Technology in Nursing Education
}

\author{
Five Axioms
}

\begin{abstract}
$B$ erized literature search was done using online library services, articles were printed from e-journals, and a word-processing program was accessed on a lap-top personal computer. Such use of technology is well established and pervasive in higher education. It is so common as to be often transparent. For the past 30 vears, the world has been host to a phenomenon the RAND organization calls the "information revolution." The United States has been a leader in developing and absorbing the new technologies into the patterns of everyday life. Most Americans, if they think about it at all, would say that the information revolution is inevitable, irresistible, and of benefit to society. ${ }^{1}$ This article presents five axioms for nurse educators trying to adjust to the changes in nursing education inspired by technology
\end{abstract}

\section{Axiom 1: The genie's out of the bottle}

Despite, or perhaps because of, its characterization as a caring profession, nurses were quick to embrace technological change to improve patient care. Computerized equipment for diagnosis, treatment monitoring, and documentation of care, as well as the technology involved in research and information dissemination, are

Affiliation: Term Assistant Professor, School of Nursing, Cleveland State University, Cleveland, Ohio

Correspondence: 1860 E 22nd St, Rhodes Tower 911, Cleveland, $\mathrm{OH} 44114$ 4435 (Cdelgado@aol.com). common. The procedure book is likely to be a program on a personal computer, laboratory data are quickly accessible by computer, and orders are directly transcribed to the computerized patient record.

Faculty have to function in this increasingly complex environment. Lenburg identifies the tremendous expansion of knowledge and the use of technology and the Internet as a significant issue for nursing education. ${ }^{2}$ She raises the issue of information overload and the difficulty of discerning the accuracy of information sources on the Internet as problems for students. The challenge for faculty is the need to respond rapidly to technological changes despite limited time for reflection and to creatively incorporate these changes into the curriculum.

The trends in higher education to incorporate technology and view education as a business are occurring almost simultaneously, and are probably not coincidental. Those in higher education are addressing the requirements of nontraditional learners including the need to establish distance-learning opportunities and to find cost-effective methods of operation. ${ }^{3}$ Economics is the key to technology in education. Whatever increases access or reduces costs is here to stay. Institutions of higher learning that do not accept or even embrace technology will not survive. Education cannot be the last bastion of the Luddite.

\section{Axiom 2: Don't be afraid}

Foster notes "widespread skepticism remains about the products and qual- ity of technology." 3(p116) In contrast, Doty refers to it as an "enabling" technology. Assuming that technology is a tool to help one work smarter, not necessarily harder, then technology enhances our reach and expands the repertoire of our teaching skills. For example, simulations of patient care situations can be invaluable for introducing students to both skill acquisition and creative thinking.

The learning curve required to acquire technological skills intimidates many faculty. Computer phobia and the need for adequate faculty development, education, and support with technology are critical issues in managing technological change in education. ${ }^{5}$ Green ${ }^{6}$ notes that the trajectory of expectation and experience in the acquisition of technology may differ, but nurse educators must have the same faith in their own ability to learn as they have for their students. Expect no less of ourselves than we do of them; faculty must be role models for the technology learning experience.

\section{Axiom 3: Be afraid}

One difficulty with electronic communication is the acontextual nature of the message. By removing nonverbal cues, communication can be altered and obscured. Teaching strategies that rely heavily on electronic communication must deal with the disconnect between teacher and learner. How that is to be done has not been researched. Volovic ${ }^{7}$ muses that the depersonalization of computerized technology can create a sense of separation from personal experience similar to Durkheim's description of "anomie." 
A student's personal experience will influence the degree to which he or she is prepared to use technology The Rand conference report on the information revolution states "technology has a tendency to exacerbate differences within a society." 1(pxiii) Individuals with established familiarity with technology have a learning advantage when those technologies are integrated into the teaching plan. For example, students with greater resources or those who graduate from school systems with greater resources would have an edge. The information poor would become a new disenfranchised group.

Another reason for unease is the subtle shift of power related to the spread of information technology. Traditional sources of knowledge and authority may be perceived as less knowledgeable if the information (which is power) is not immediately associated with them. The prestige of a university does not necessarily transfer to their Web site. All sources appear to be equally credible on the Internet, and search engines are commonly indiscriminate in the results they produce. Instructors and students must find a way to separate the wheat from the chaff and the university will have to find a way to market the advantage of their offerings to students who have a much larger menu of options than ever before.

\section{Axiom 4: Technology is in dynamic evolution}

Technology and education should be viewed as an exemplar for life-long learning. If there is a constant in technology, it is the accelerating rate of obsolescence. There is always something new to know, change and adaptation are constant. The newest and the latest in technology have a very short half-life.

Volovic finds the analogy between evolution and technology in education when he states "Evolution is about adaptation, so is education" $(7$, p.33). Education makes a profound change in a person's life. Learning implies growth. Humans adapt physically through genetic mutation and cognitively through education.

\section{Axiom 5: Make technology serve your needs}

One way to guide the evolutionary process of technological change is to make demands on the system. Rather than letting technology drive education, education should proactively make clear what education needs from technology. Articulate goals and then the technology to achieve those goals can be researched. If a problem or purpose can be clearly identified. the technology is usually available.

A common problem related to technology is that a program or piece of equipment will be touted as the "latest thing" even though it does not fit the user's needs. If the stated goal is to increase enrollment in the nursing program, then technology must be aimed at that specific purpose. The technological choices should be a response to stated needs of education and not a stimulus to change for its own sake. When "our technologies begin to shape us in their image and likeness, we are heading in the wrong direction." 7(p206)

\section{Looking Ahead}

What is the future of nursing education and technology? For many years, the clarion call has been for education to embrace technology. Education, notably nursing education, has responded by teaching technological skills and integrating technology into teaching strategies. In the future, nursing education will find it necessary to make stronger connections with the community and business of healthcare.

Given that academe must become involved and invested in the community, one pattern for the future is partnerships outside the university to share major capitol expenditures (high-priced technological equipment) and to access experienced and clinically skilled instructors. The Boyer model outlines four dimensions of scholarship (discovery, integration, application, and teaching) that work very well with a community-involved, technologically savvy nursing faculty. ${ }^{8}$

Inherent in this move to interface with the community is a shift in focus from the product, a graduate with thinking skills, to the process that enriches both university and community. Freer communication, greater accessibility, and sharing human and technological resources are mutually beneficial. The product of this new collaboration will be a graduate with finely tuned critical thinking skills, armed with practical knowledge and resistant to reality shock on entering the working world.

Technology has undeniably changed nursing education and it will doubtless continue to do so. Whether the changes are positive or negative will depend much on nursing educators. If we are afraid, or if we expect technology to do our work for us, we will invest that technology with power at our own expense. If we keep technology in perspective and maintain a sense of balance, we will be empowered. Technology is inevitable, irresistible, and good for the profession.

\section{References}

1. Hundley RO, Anderson RH, Bikson TK, et al. RAND Conference Proceedings: The Global Cause of the Information Revolution: Political, Economic and Social Consequences. Santa Monica, Calif: RAND; 2000.

2. Lenburg $\mathrm{CB}$. The influence of contemporary trends and issues in nursing education. In: Cherry B, Jacobs SR, eds. Contemporary Nursing: Issues, Trends and Management. 2nd ed. St Louis, Mo: Mosby; 2002:65-94.

3. Foster L. Technology: Transforming the landscape of higher education. Rev Higher Educ. 2001;21(5):115-124.

4. Doty P. Fish, fire and fallacies: Approaches to information technology and higher education. Portal: Libraries and the Academy. 2002;2(4):647-652

5. Bates AW. Managing Tecbnological Change: Strategies for College and University Leaders. San Francisco, Calif: Jossey-Bass; 2000.

6. Green L. Communication Technology and Society. London: Sage Publications; 2002.

7. Volovic TS. Digital Mythologies: The Hidden Complexities of the Internet. New Brunswick, NJ: Rutgers University Press; 2000.

8. Boyer EL. Scholarbip Reconsidered: Priorities of the Professoriate. Princeton, NJ: The Carnegie Foundation for the Advancement of Teaching; 1990 . 